\title{
ENVIRONMENTAL RISKS OF THE PRIPYAT RIVER IN A CHANGING CLIMATE
}

\author{
Aliaksandr Volchak ${ }^{1}$, Aleh Meshyk ${ }^{1, *}$, Yury Mazhayskiy ${ }^{2}$, Anatoliy Rokochynskiy ${ }^{3}$ and \\ Jerzy Jeznach ${ }^{4}$ \\ ${ }^{1}$ Brest State Technical University, Moskovskaya str. 267, Brest, 224017, Belarus \\ ${ }^{2}$ VNIIGiM of A.N. Kostiakov, Bolshaya Akademicheskaya str. 44, b. 2, Moscow, 127550, Russia \\ ${ }^{3}$ National University of Water and Environmental Engineering, Soborna str. 11, Rivne, 33028, Ukraine \\ ${ }^{4}$ Warsaw University of Life Sciences - SGGW, Nowoursynowska str. 166, Warsaw, 02-787, Poland
}

\begin{abstract}
The paper considers the hydrological characteristics of the Pripyat River. At the same time, extreme hydrological situations are described - floods and low water levels. The influence of land reclamation carried out in the catchment area on the river runoff was established. Forecast estimates of changes in the flow of the Pripyat River and its tributaries are given. For this, a method of hydrological and climatic calculations based on the joint solution of water and heat and power balances was adopted.
\end{abstract}

Keywords: river, flood, low water, runoff, climatic changes.

\section{Introduction}

Currently, the problem of water among the problems facing humanity is more and more often put forward in the first place as the state and development of the biosphere and human society are closely dependent on the state of water resources $[1,2]$. Water problems arise when: insufficient water; its unsatisfactory quality; inconsistency of the water regime with the optimal functioning of ecosystems and economic objects; excessive moisture and floods [3]. The first three problems in the global aspect were generated by the past XX century and the fourth has been with humanity since ancient times. All these problems are to some extent inherent in the Pripyat river basin.

The Pripyat is the main river of Polesie. It is an average European river in the Black Sea basin and belongs to the plain type with a predominance of elements of snow supply. The length of the Pripyat River is $761 \mathrm{~km}$, the catchment area is 173.7 thousand $\mathrm{km}^{2}$. The general direction of the river flow is latitudinal from west to east which is not typical for the rivers of Eastern Europe. The channel at the source is canalized, the rest of the length is meandering, slightly meandering, ramified, replete with bays and adjoining old rivers. Most of the tributaries are fully or partially canalized. The largest tributaries of the Pripyat are the Yaselda, Lan, Sluch, Ptich, Pina, Bobrik, Tsna, Ippa, Stokhod, Goryn, Stviga, Ubort rivers [4, 5, 6, 7, 8].

The aim of this work is to assess the current environmental risks of the Pripyat River now and in the future.

\footnotetext{
* Corresponding author: omeshyk@gmail.com
} 


\section{Method}

The methodological basis of research is the scientific provisions on the stochastic nature of the variability of the water regime of rivers which made it possible to use statistical methods for analyzing time series [9]. In addition, methods of water and heat energy balance of the underlying surface, mathematical modeling were used. The systematic analysis of the accumulated information, the comparative-geographical method made it possible to synthesize the most important key positions of the spatial-temporal fluctuations in runoff $[10,11]$.

We have adapted the method of hydrological and climatic calculations based on the joint solution of the equations of water and heat and power balances [12] for predictive estimates of river runoff changes in the basins. A multivariate model based on the hydrological and climatic hypothesis of V.S. Mezentsev [13] has been developed it includes a standard water balance equation for a land area with an independent assessment of the main balance elements (precipitation, evapotranspiration and climatic runoff) in an annual section. The developed model is used to assess possible changes in river water resources depending on certain hypotheses of climatic fluctuations and anthropogenic impacts on the elements of catchments.

The system of equations for the water balance of the river catchment for a certain period of time has the form

$$
\left.\begin{array}{l}
Y_{K}(I)=H(I)-E(I) \pm \Delta W(I) ; \\
E(I)=E_{m}(I)\left[1+\left(\frac{\left.\frac{E_{m}(I)}{W_{H B}+V(I)}\right)^{1-r(I)}}{\frac{K X(I)+g(I)}{W_{H B}}+V(I)}\right)^{n(I)}\right]^{-\frac{1}{n(I)}} ; \\
V(I+1)=V(I) \cdot\left(\frac{V_{c p}(I)}{V(I)}\right)^{r(I)} ; \\
V_{c p}(I)=\left(\frac{\frac{K X(I)+g(I)}{W_{H B}}+V(I)}{\frac{E_{m}(I)}{W_{H B}}+V(I)^{1-r(I)}}\right)^{\frac{1}{r(I)}} ; \\
H(I)=K X(I)+W_{H B}(V(I)-V(I+1)),
\end{array}\right\}
$$

where $Y_{K}(I)$ - total climatic runoff, mm; $H(I)$ - total resources of moisture, mm; $E$ (I) total evaporation, $\mathrm{mm} ; \Delta W(I)$ - change in moisture reserves of the active layer of soil, $\mathrm{mm}$; $E_{m}(I)$ - the maximum possible total evaporation, $\mathrm{mm}$; $W_{H B}$ - the smallest soil moisture capacity, mm; $V(I) / W(I) / W_{H B}$ - relative humidity of soils at the beginning of the calculating period; $K X(I)$ - the sum of the measured precipitation, $\mathrm{mm} ; g$ (I) - ground component of the water balance, $\mathrm{mm} ; r(I)$ - a parameter that depends on the water-physical properties and the mechanical composition of the soil; $n(I)$ - a parameter that takes into account the physical and geographical conditions of the runoff; $I$ - averaging interval.

The obtained values $V_{c p}(I)$ are compared with the relative value of the total moisture capacity $V_{P B}$. If $V_{c p}(I) \leq V_{P B}$, then the calculated value of the relative average humidity is taken, otherwise, when $V_{c p}(I) \geq V_{P B}$ is taken to the calculation $V_{c p}(I)=V_{P B}$, the difference $\left(V_{c p}(I)-V_{P B}\right) W_{H B}$ refers to the surface runoff.

The amount of atmospheric precipitation in the months of the cold period minus the amount of total evaporation is transferred to the flood period, i.e. for the month of March. The maximum possible total evaporation is found according to the method described in [14].

The solution of the system of equations (1) is carried out by the iterative method until the value of the relative humidity of the soil at the beginning of the calculated interval is equal to the value of the relative humidity at the end of the last interval. When calculating, the initial value of moisture is taken equal to the value of the smallest moisture capacity, i.e. 
$W(1)=W_{H B}$ from where $V(1)=1$. The convergence of the solution of the system is achieved already at the fourth calculation step.

The climatic runoff is adjusted using coefficients that take into account the influence of various factors on the formation of streamflow, i.e.

$$
Y_{P}(I)=k(I) \cdot Y_{K}(I),
$$

where $Y_{P}(I)$ is the total channel runoff, $\mathrm{mm} ; k(I)$ is a coefficient that takes into account the hydrographic characteristics of the catchment area.

Modeling the water balance of the investigated river is implemented in the form of a computer program and is carried out in two stages. At the first stage, the model is adjusted according to the known components of the water and heat balances of the investigated river. When setting up the model, the goal is to achieve the best match between the calculated climatic and channel flows. The first stage ends with the construction of graphs of the climatic and channel runoff and the output of the modeling error.

The coincidence of the measured and calculated runoff indicates the correctness of the model. The obtained parameters of the model were used in a numerical experiment.

The second stage is a direct calculation of the water balance of the investigated river using the parameters obtained during model calibration. The calculation of the elements of the water balance of the investigated river is carried out taking into account the specific features of the considered catchment [15].

The solution of the water balance equation for the catchment area is associated with the determination of the average value of those elements that are monitored at separate points of the catchment area. Therefore, one of the main components of modeling the water regime is the correct assessment of climatic characteristics and their averaging over the catchment. This problem is considered in detail in [16].

There were problems with determining the parameters for the winter months when setting up the models according to the proposed method. The fact is that the model did not accurately take into account the recent thaws that have become more frequent. Therefore, the model was adjusted to take into account thaws. The difference between the channel and climatic runoff obtained when setting up the model related to the runoff formed during thaws which was fixed in the model settings. When predicting the future runoff, this component was added directly to the runoff and its value was subtracted from the atmospheric precipitation of the corresponding month and precipitation was transferred to the flood period minus the total evaporation and runoff during the thaw period. Moreover, the amount of runoff during the thaw period was adjusted taking into account the predicted temperature of the corresponding month. In the first approximation, the value of this runoff can be taken from the ratio of monthly air temperatures and the runoff value during the thaw period obtained when setting the model.

Forecast estimates of river runoff changes were carried out according to the following scheme. The model was adjusted according to long-term average data on river runoff, atmospheric precipitation, air temperature and air humidity deficit. Then the predicted values were entered for the corresponding perspective for those weather stations that were used when setting up the model. Model settings were read and predictive estimates were made. The obtained values of the climatic runoff were compared with each other according to the ratio $\Delta_{k l}=Y_{k l}^{p r} / Y_{k l}^{s o v}$. $\cdot 100 \%$. A direct predictive estimate of the channel runoff was found from the ratio $Q^{p r}=Q^{s o v} \cdot \Delta_{k l} / 100, \mathrm{~m}^{3} / \mathrm{s}$.

As the main source materials, we used standard observational data on the hydrometeorological network, stock materials of various organizations and institutions for the period of instrumental observations as well as cartographic and published sources. 


\section{Results and discussion}

The average annual discharge of the Pripyat River at the mouth is $450 \mathrm{~m}^{3} / \mathrm{s}$. The intraannual distribution of runoff is characterized by unevenness. The runoff of the spring period averages about $61 \%$, summer-autumn - $23 \%$, winter - $16 \%$ of the annual runoff. The water discharge of the Pripyat River in the alignment of the city of Mozyr of various supplies is presented in table. 1. Calculations were performed based on the series of observations for more than 130 years using a three-parameter gamma distribution.

Table 1. Water flow rate of the Pripyat river with different availability, $\mathrm{m}^{3} / \mathrm{s}$.

\begin{tabular}{|l|c|c|c|c|c|c|}
\hline Water flow view & $\begin{array}{c}\text { Coefficients of } \\
\text { variability }\end{array}$ & $\boldsymbol{Q}_{\mathbf{c p}}$ & $\boldsymbol{Q}_{\mathbf{p}=\mathbf{1 \%}}$ & $\boldsymbol{Q}_{\mathbf{p}=\mathbf{5 \%}}$ & $\boldsymbol{Q}_{\mathbf{p}=\mathbf{9 5 \%}}$ & $\boldsymbol{Q}_{\mathbf{p}=\mathbf{9 9} \%}$ \\
\hline Annual & 0.31 & 392 & 713 & 380 & 221 & 171 \\
\hline $\begin{array}{l}\text { Maximum spring } \\
\text { flood }\end{array}$ & 0.87 & 1771 & 7154 & 4321 & 494 & 331 \\
\hline $\begin{array}{l}\text { Maximum rainfall } \\
\text { floods }\end{array}$ & 0.78 & 376 & 1350 & 861 & 117 & 80.4 \\
\hline $\begin{array}{l}\text { Minimum summer- } \\
\text { autumn }\end{array}$ & 0.49 & 155 & 359 & 272 & 80.5 & 64.6 \\
\hline Minimum winter & 0.72 & 156 & 569 & 346 & 53.0 & 38.9 \\
\hline
\end{tabular}

\section{Floods}

Floods rank first among natural disasters in terms of the number of casualties and damage caused. At the same time, paradoxical as it may seem, until now there are no reliable long-term forecasts of their occurrence, reliable and generally accepted methods for calculating the damage caused by them and a generally accepted concept of protection [17].

Flood usually begins on the Pripyat River in the first half of March but in some years it can shift to February or April. The average long-term duration of flooding of the floodplain of the Pripyat River is 80 - 110 days and sometimes up to 150 - 180 days. The width of the spring flood varies from 5 to $15 \mathrm{~km}$, the largest in the area of Pinsk reaches $30 \mathrm{~km}$. The depth of flooding is mainly $0.3-0.8 \mathrm{~m}$, in some places $2-2.5 \mathrm{~m}$ [4]. Flooding in the floodplain of the Pripyat River from floods of varying availability is shown in Fig.1 [6].

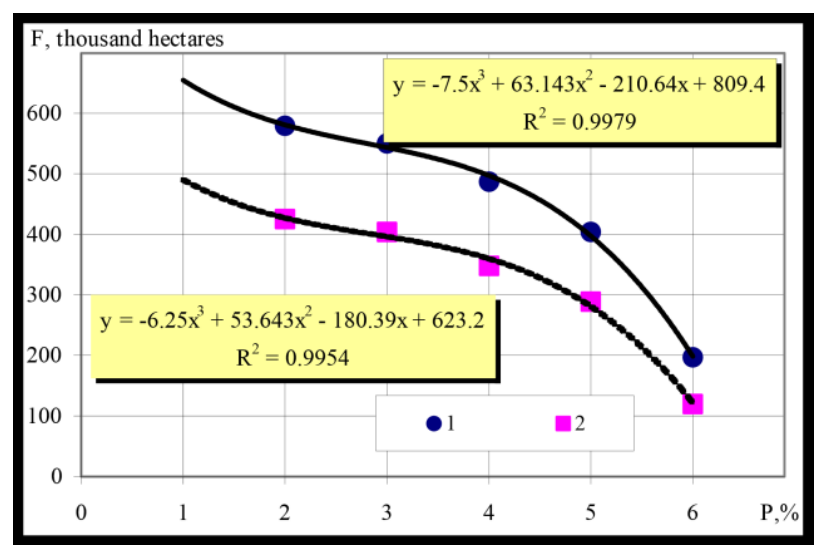

Fig. 1. Areas of flooding of the floodplain of the Pripyat River, depending on the availability of the water level: 1 - total along the floodplain; 2 - within Belarus.

The maximum flood on the Pripyat River was noted in 1845 and was so catastrophic that it probably can be attributed to the group of maximum possible ones in our climatic 
epoch. It is a unique hydrological phenomenon with very rare recurrence. The maximum level exceeded the zero of the graph of the modern gauging station near the city of the city of Mozyr by $675 \mathrm{~cm}$ and the water discharge is estimated at $11000 \mathrm{~m}^{3} / \mathrm{s}$ and can be approximately considered repeating no more than once every 800 years [18]. The last significant flood was in 1999. Table 2 shows the water discharge of the 10 most significant floods in Pripyat and their availability [19].

Table 2. Maximum water discharge (Q) of spring flood and supply $(\mathrm{P})$ of the Pripyat River - the city of Mozyr.

\begin{tabular}{|c|c|c|c|c|c|c|c|c|c|c|}
\hline Years & $\mathbf{1 8 4 5}$ & $\mathbf{1 8 7 7}$ & $\mathbf{1 8 9 5}$ & $\mathbf{1 8 8 8}$ & $\mathbf{1 8 8 9}$ & $\mathbf{1 9 4 0}$ & $\mathbf{1 9 7 9}$ & $\mathbf{1 9 3 2}$ & $\mathbf{1 9 7 0}$ & $\mathbf{1 9 5 8}$ \\
\hline$Q, \mathrm{~m}^{3} / \mathrm{s}$ & 11000 & 7500 & 5670 & 5100 & 4700 & 4520 & 4310 & 4220 & 4140 & 4010 \\
\hline$P, \%$ & 0.8 & 1.6 & 2.3 & 3.1 & 3.9 & 4.7 & 5.4 & 6.2 & 7.0 & 7.6 \\
\hline
\end{tabular}

Freshet level rises in contrast to floods occur irregularly and, in terms of the maximum discharge and the runoff layer, freshets are as a rule significantly less than the high water maximums. However, rain freshets in 1952, 1960, 1974, 1993, 1998 on many watercourses and sections of the Pripyat itself exceeded floods and caused significant damage to the national economy. Even local freshets on the tributaries can cause significant level rises in the lower reaches of the Pripyat River because of the downward movement of the freshet wave. The height of freshets in the middle and lower reaches of the Pripyat reaches $2-3.5 \mathrm{~m}$ above the pre-rise level $[20,21]$.

\section{Low water}

The high water is replaced by a summer-autumn low-water period characterized by significant variability. Summer low water is usually lower than winter and is interrupted almost every year by rain freshets. The winter low-water period is often interrupted by thaws which result in winter freshets in some years exceeding floods [22].

The conditions for the formation of low-water runoff of rivers in general can be considered favorable since the territory of Polesye is located in the zone of excessive moisture and the outflow of groundwater into the river network is more or less long-term and constant. The minimum levels and runoff of water in summer are observed at high average daily air temperatures and with prolonged periods of absence of precipitation; in winter - at low temperatures. There was a drying up of watercourses in Polesie even with catchment areas over $1000 \mathrm{~km}^{2}$ in dry years $(1939,1951,1952$, etc.). Freezing is observed only on small rivers and for a short time.

Most low-water period of summer-autumn low water is mainly observed in July August, at least - in September. Its duration for the Pripyat River is 85-90 days.

The winter low-water period is usually stared at the end of December. The earliest dates for the onset of low water fall on the end of October - early November and the latest - in January, the end - with the beginning of the spring flood.

Zero runoff within the catchment area of Pripyat was noted in 17 watercourses with catchment areas of $11-1280 \mathrm{~km}^{2}$. The average duration of one case of zero runoff can reach 195 days in summer and 75-100 days in winter.

The values of the smallest average monthly summer discharges naturally decrease over the territory of Polesie from the northwest and north to the south and southeast, subject to geographic zoning on large and medium rivers. However, an intrazonal nature of changes is found on small rivers, depending on local hydrogeological features - the presence and thickness of groundwater horizons, the nature of their opening by river valleys and the conditions for their discharge.

The most water-abundant are aquifers in fractured and karst carbonate-sulfate rocks of the Upper Cretaceous and Neogene. Outlets of chalk waters are observed within the Polesie lowland in the form of ascending springs with a flow rate of up to $200 \mathrm{~m}^{3} / \mathrm{h}$. These waters feed a number of lakes, numerous bog massifs and partially right-bank tributaries of the Pripyat - the 
rivers Turya, Stokhod, Goryn, Styr, etc. The modulus of the minimum average daily runoff of these rivers $97 \%$ of availability varies from $0.07-0.181 /\left(\mathrm{s} \cdot \mathrm{km}^{2}\right)$. Those rivers which are fed from the aquifers of alluvial and fluvioglacial sediments have low modules of minimum runoff and in dry years their runoff completely stops for a period from 15 to 120 days. Cessation of runoff on these rivers is also possible during cold, non-thaw winters [23].

\section{Anthropogenic impacts on river runoff}

There has been a discussion about the impact of land reclamation on river flow since the $50 \mathrm{~s}$ of the last century. The main impact on the water regime of the Pripyat River was exerted during the period of large-scale hydrotechnical reclamation of the Polesie lowland. At the same time, the water resources of Polesie were more strongly affected by anthropogenic impacts than other regions. $23 \%$ of the territory was drained, the total length of the open reclamation network exceeded $65.000 \mathrm{~km}$, the hydrographic network was significantly transformed, especially if we take into account the straightening and deepening of the Pripyat River itself and its large tributaries. In addition, the embankment of certain sections of the Pripyat River and the construction of polder reclamation systems which exclude flooding of the embanked floodplain sections led to the fact that the groundwater dropped by 1.0-1.5 m it, followed by a decrease in water levels in the rivers and in some - up to dryness. All this resulted in a change in the hydrological regime of the rivers. Analysis of the change in the Pripyat River runoff showed an increase in the average annual runoff of the Pripyat River during the period of active reclamation in all months of the year, except for April and May [24].

Recently, maximum losses from irrecoverable water consumption are small and are within the measurement error.

Analysis of the dynamics of the water flow of the Polesie rivers showed that starting from the mid-60s of the last century the average annual, minimum summer and winter discharges have a steady tendency to increase, at the same time, the spring flood flow decreases (Fig. 2).

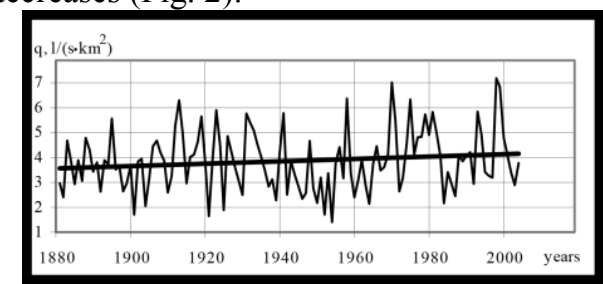

a)

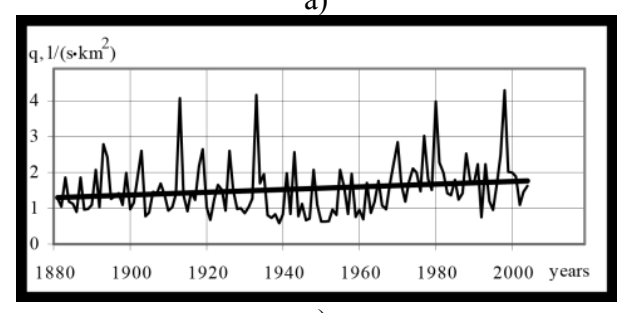

c)

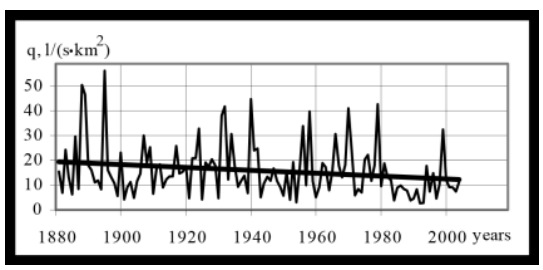

b)

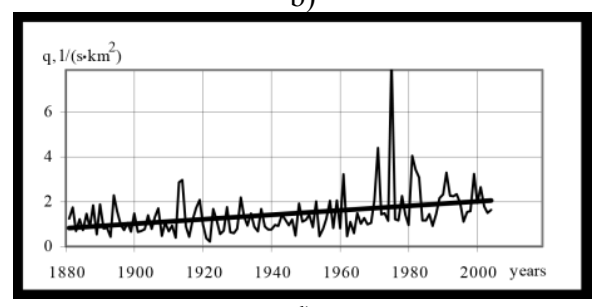

d)

a) average annual; b) maximum spring floods; c) minimum summer-autumn; d) minimum winter

Fig. 2. Dynamics of the modules of the water flow of the Pripyat river in the alignment of the city of Mozyr.

\section{Assessment of changes in the water regime under various future climate scenarios}

Comparative analysis of river runoff changes in the Pripyat basin for hydrological stations in the monthly average and in the average annual sections for the period from 1987 to 2015 in relation to the period from 1961 - 1986 [16] showed that:

- the average annual runoff is insignificantly downward (maximum - by $9 \%$ ); 
- there was a significant decrease in the runoff of the spring flood by $42 \%$ with an earlier onset of its peak;

- there was an increase in runoff in winter by $20 \%$;

- runoff in summer did not change very significantly over the entire period from 1961 to 2015 , however, in recent years there has been a significant decrease in runoff which was even less than the minimum for the entire indicated period.

Predictive estimates of changes in the river runoff of the rivers of the Pripyat basin for the period up to 2035 were made according to the method of hydrological and climatic calculations proposed above. In this case, the results of assessing the actual climate change and river runoff for the period from 1961 to 2015 were used and an updated forecast of climate change for the period up to 2035 in these river basins taking into account the multimodel ensemble of four scenarios recommended by the IPCC [25] as well as regional climate variability. Taking into account the use of the most conservative climate change scenarios, the temperature rise in the basin on average per year can reach $1.9^{\circ} \mathrm{C}$ with a maximum increase in winter by $2.3{ }^{\circ} \mathrm{C}$, in summer - by $1.9^{\circ} \mathrm{C}$, in spring and autumn - by about $1.7^{\circ} \mathrm{C}$. At the same time, the annual amount of precipitation will change insignificantly (in total for the year it will decrease by $2 \%$ ) with an increase in it in winter (by an average of 7\%), a maximum decrease in summer (by an average of $10 \%$ ), to a lesser extent in a decrease in spring (by $4 \%$ ) and a slight decrease in the fall (on average by $1.6 \%)$. A generalization of the results of calculations of the predicted flow change in the Pripyat River basin for the period up to 2035 is given in Table. 3 [16].

Table 3. Forecast of changes in surface runoff until 2035 for the Pripyat River and its tributaries, in $\%$ of the current state.

\begin{tabular}{|l|c|c|c|c|c|}
\hline \multicolumn{1}{|c|}{ River - settlement } & Winter & Spring & Summer & Autumn & Average annual \\
\hline Pripyat - Chernichi (Turov) & 4.9 & 5.5 & -19.2 & 0.6 & -2.1 \\
\hline Pripyat - Mozyr & 0.2 & 1.6 & -20.6 & -2.4 & -5.3 \\
\hline Yaselda - Bereza & -0.3 & -27.0 & -41.7 & -23.3 & -23.1 \\
\hline Yaselda - Senin & -3.9 & -10.6 & -37.7 & -11.8 & -16.0 \\
\hline Tsna - Dyatlovichi & -3.7 & -8.9 & -26.9 & -19.9 & -14.9 \\
\hline Goryn - Malye Vikorovichi & -4.0 & -11.8 & -20.1 & -16.7 & -13.2 \\
\hline Sluch - Lenin & 10.1 & 5.7 & -15.8 & 1.6 & 0.4 \\
\hline Ubort - Krasnoberezhe & -13.4 & -5.6 & -25.2 & -38.8 & -20.8 \\
\hline Ptich - Luchitsy & 10.3 & -0.2 & -24.0 & 16.7 & 0.70 \\
\hline Shat - Shatsk & -0.2 & -9.2 & -10.7 & -4.4 & -6.1 \\
\hline Oressa - Andreevka & -14.7 & -10.7 & -28.4 & 5.4 & -12.1 \\
\hline average for the basin: & -1.3 & -6.5 & -24.6 & -8.5 & -10.2 \\
\hline
\end{tabular}

With climate change according to scenario $\mathrm{A} 1 \mathrm{~B}$, based on the results of calculations, the following conclusions can be drawn about the predicted change in runoff in the Pripyat River basin until 2035 [16]:

- a slight decrease in the average annual runoff;

- a slight increase in runoff in winter in most rivers - on average for the basins up to $2.1 \%$, up to a maximum of $25 \%$ and for some rivers the change in runoff will be insignificant or even likely to decrease;

- in the spring period, with rare exceptions, the runoff is likely to decrease by an average of $5.5 \%$, maximum - by $25 \%$;

- in the summer period, a significant and maximum of all periods of the year is predicted to decrease the runoff - on average by $20 \%$, maximum - by $40 \%$;

- in the autumn period (especially at the beginning of autumn - until mid-October), a predominant decrease in runoff is likely - by an average of $8.5 \%$, maximum by $35 \%$, in the remaining autumn months the runoff will change insignificantly. 
Climate change scenario B1 is more severe and leads to large changes in river flow and sharper differences between the northern and southern parts of the republic, between medium and small rivers. Unevenness and multidirectionality are noted in certain months with an increase in runoff as a whole for the year.

Detailed results of the forecast runoff for the period up to $2035\left(\mathrm{~m}^{3} / \mathrm{s}\right)$, changes in runoff in absolute values $\left(\mathrm{m}^{3} / \mathrm{s}\right)$ and in relative values $(\%)$ are given in [16].

\section{Conclusion}

The water risks of the Pripyat River are far from being completely neutralized. Therefore, on the basis of the scientific results obtained, it is necessary to develop measures to minimize possible negative consequences in the event of a change in the regime of water.

Further research should be focused on the following main areas:

- prevention and reduction of negative consequences from floods;

- improving the quality of natural waters;

- protection of water sources in the design, construction and operation of public facilities;

- management of the regime of natural waters, ensuring the biosphere functioning of natural ecosystems;

- creation of basin schemes for water resources management in Polesie.

\section{References}

1. Farhan, Hussain \& Wagan, \& Khoso, Salim. (2013). Water shortage; its causes, impacts and remedial measures.

2. Impacts of climate change on water resources in Spain (2012) T. Estrela, M.A. PérezMartin, E. Vargas. Hydrological Sciences Journal. Vol. 57. № 6., 1154-1167.

3. Impact of climatic change on river discharge in the driest region of Poland (2014) Piotr Ilnicki [and others]. Hydrological Sciences Journal. Vol. 59. № 6, 1117-1134.

4. Блакітная кніга Беларусі: Энцыкл. (The Blue Book of Belarus : Encyclical.) /Belarus. Encyclical; Editorial Board: N.A. Dzisko et al. - Minsk, 1994. - 415 p. (In Russian).

5. Природообустройство Полесья (Environmental Engineering in Polesye) : monograph : in 4 books / edited by Yu. Mazhayskiy, A. Rokochynskiy, A. Volchak, A. Meshyk, J. Jeznach. - Ryazan: Meshchersk office of VNIIGiM of A. N. Kostiakov, 2017. - Book 2: Ukrainian Polesye - V. 1. - 902 p. (In Russian).

6. Природообустройство Полесья (Environmental Engineering in Polesye) : monograph : in 4 books / edited by Yu. Mazhayskiy, A. Rokochynskiy, A. Volchak, A. Meshyk, J. Jeznach. - Ryazan : Meshchersk office of VNIIGiM of A. N. Kostiakov, 2018. - Book 1 : Belarusian Polesye. - V. 1 : Natural Resources Potential. - 408 p. (In Russian).

7. Природообустройство Полесья (Environmental Engineering in Polesye) : monograph : in 4 books / edited by Yu. Mazhayskiy, A. Rokochynskiy, A. Volchak, A. Meshyk, J. Jeznach. - Ryazan: Meshchersk office of VNIIGiM of A. N. Kostiakov, 2018. - Book 2: Ukrainian Polesye - V. 2 . - 804 p. (In Russian).

8. Природообустройство Полесья (Environmental Engineering in Polesye) : monograph : in 4 books / edited by Yu. Mazhayskiy, A. Rokochynskiy, A. Volchak, A. Meshyk, J. Jeznach. - Ryazan : Meshchersk office of VNIIGiM of A.N. Kostiakov, 2019. - Book 1 : Belarusian Polesye - V. 2 : Transformation and Use of Natural Resources. - 503 p. (In Russian).

9. Liebscher, H.J. (1993) Hydrology for the water management of large river basins / H.J. Liebscher. Hydrological Sciences Journal. Vol. 38. №1, 1-13. 
10. Wrzesiński, D. (2018) Detection of changes in flow regime of rivers in Poland / D. Wrzesiński, L. Sobkowiak. J. Hydrol. Hydromech. Vol. 66. № 1, 55.

11. Hannaford, J. (2012) Trends in seasonal river flow regimes in the UK / J. Hannaford, G. Buys. Journal of Hydrology. 475. 158-174.

12. Мезенцев, В.С. Гидрологические расчеты в мелиоративных целях (Hydrological calculations for reclamation purposes) / V.S. Mezentsev. - Omsk, 1982. - 84 p. (In Russian).

13. Мезенцев, В.С. Гидролого-климатическая гипотеза и примеры ее использования (Hydrological and climatic hypothesis and examples of its use) / V.S. Mezentsev // Water resources, 1995. - Volume 22, № 3. - P. 299-301. (In Russian).

14. Волчек, А.А. Закономерности формирования водного баланса речных водосборов Беларуси: Формирование водного баланса Беларуси (Regularities of formation of water balance of river watersheds of Belarus: Formation of water balance of Belarus) / A.A. Volchek // Saarbrucken: LAP LAMBERT Academic Publishing GmbH \& Co. KG, 2011. - 387 p. (In Russian).

15. Волчек, А.А. Оценка трансформации водного режима малых рек Белорусского Полесья под воздействием природных и антропогенных факторов (на примере р. Ясельда) (Estimation of the transformation of the water regime of small rivers of the Belarusian Polesie under the influence of natural and anthropogenic factors (on the example of the Yaselda River)) / A.A. Volchek, S.I. Parfomuk // Water management of Russia: problems, technologies, management. - Ekaterinburg, 2007. - № 1. - P. 50-62. (In Russian).

16. Водные ресурсы Беларуси и их прогноз с учетом изменения климата (Water resources of Belarus and their forecast taking into account climate change) / A.A. Volchek, V.N. Korneev, S.I. Parfomuk, I.A. Bulak; under common ed. A.A. Volchek, V.N. Korneev. - Brest: Alternativa, 2017. - 228 p. (In Russian).

17. Meshyk, A., Barushka, M, Marozava, V. (2020) Snow as a Contributor to Spring Flooding in Belarus. Environmental Science and Pollution Research. 1-11. https://doi.org/10.1007/s11356-020-09638-8.

18. Логинов, В.Ф. Весенние половодья на реках Беларуси: пространственно-временные колебания и прогноз (Spring floods on the rivers of Belarus: spatial-temporal fluctuations and forecast) / V.F. Loginov, A.A. Volchek, An.A. Volchek - Minsk, 2014. 244 p. (In Russian).

19. Volchak, A. A., Meshyk, A. P., Sheshka, M. M. et al. (2016). Floods on the territory of Polesie. Procedia Engineering. 162, 91-97. https://doi.org/10.1016/j.proeng.2016.11.020

20. Волчек, А.А. Опасные гидрологические явления на р. Припяти (Hazardous hydrological phenomena on the Pripyat river) / A.A. Volchek, An.A. Volchek // Extreme hydrological situations / under common ed. N.I. Koronkevich, E.A. Barabanova, I.S. Zajceva. - Moscow, 2010. - P. 295-322. (In Russian).

21. Волчек, А.А. Мониторинг, оценка и прогноз чрезвычайных ситуаций и их последствий (Monitoring, assessment and forecast of emergency situations and their consequences) / A.A. Volchek, P.S. Pojta, P.V. Shvedovskij // Brest, 2012. - 423 p. (In Russian).

22. Black, A.R. (1997) Seasonality of flooding: A case study of North Britain / A.R. Black, A. Werritty. J. Hydrol. 195. 1-25.

23. Мониторинг, использование и управление водными ресурсами бассейна р. Припять (Monitoring, use and management of water resources in the Pripyat river basin) / under common ed. M. Yu. Kalinin and A. G. Obodovskij. - Minsk, 2003. - 269 p. (In Russian).

24. Логинов, В.Ф. Антропогенное воздействие на водные ресурсы Беларуси (Anthropogenic impact on water resources in Belarus) / V.F. Loginov, M.Yu. Kalinin, V.F. Ikonnikov. - Minsk, 2000. - 284 p. (In Russian). 
25. IPCC, 2014: Climate Change 2014: Impacts, Adaptation, and Vulnerability. Part A: Global and Sectoral Aspects. Contribution of Working Group II to the Fifth Assessment Report of the Intergovernmental Panel on Climate Change [Field, C.B., V.R. Barros, D.J. Dokken, K.J. Mach, M.D. Mastrandrea, T.E. Bilir, M. Chatterjee, K.L. Ebi, Y.O. Estrada, R.C. Genova, B. Girma, E.S. Kissel, A.N. Levy, S. MacCracken, P.R. Mastrandrea, and L.L.White (eds.)]. Cambridge University Press, Cambridge, United Kingdom and New York, NY, USA, 1132 pp. 